\author{
ks. Michał Drożḋ \\ Uniwersytet Papieski Jana Pawła II w Krakowie
}

\title{
World Youth Day 2016 Kraków. RECENZJA KSIĄŻKI
}

Paulina Guzik, Cecilia O’Reilly, World Youth Day 2016 Kraków: The Largest European Event of the XXI Century. Communication Case Study, Wydawnictwo Naukowe Uniwersytetu Papieskiego Jana Pawła II w Krakowie: Kraków 2018, 219 stron, ISBN 978-83-7438-695-1 (print), ISBN 978-83-7438-696-8 (online).

Recenzowana monografia w języku angielskim autorstwa dwóch osób: Pauliny Guzik i Cecilii O'Reilly, zatytułowana World Youth Day 2016 Kraków: The Largest European Event of the 21st Century. Communication Case Study jest ważnym, na gruncie polskim i międzynarodowym, przedsięwzięciem dokumentującym Światowe Dni Młodzieży Kraków 2016 (World Youth Day 2016 Kraków). Publikacja ma zarówno walor naukowy ze względu na zawarte w niej unikatowe materiały źródłowe, badawcze i dokumentacyjne przedstawione w sposób syntetyczny, jak i popularno-naukowy - ze względu na założone i realizowane przez autorki cele. Sam tytuł publikacji wskazuje na potrójny walor publikacji. Po pierwsze autorki książki prezentują Światowe Dni Młodzieży Kraków 2016 (dalej: WYD 2016) jako największe dotychczas wydarzenie europejskie w XXI wieku. Chodzi tutaj o skalę i jakość wydarzenia z udziałem młodych ludzi z całego świata. Drugim walorem książki, zaznaczonym przez autorki w podtytule, jest medialno-komunikacyjny aspekt WYD 2016. W takiej perspektywie medialno-komunikacyjnej specyfika pracy ma unikatowy charakter. Trzecim walorem pracy jest jej źródłowo-dokumentacyjny charakter, który stanowi bazę dla przyszłości, zarówno w działaniach organizacyjnych, jak i badawczo-naukowych, związanych z WYD i wielkimi eventami młodzieżowymi.

Autorkom należą się wyrazy uznania za ich solidną dokumentacyjną pracę badawczą, analizę źródłową i prezentację kontekstu komunikacyjnego WYD 2016.

Publikacja jest nowatorska, ponieważ nie tylko pokazuje fenomen WYD i jego duchowego, ewangelizacyjnego i religijnego charakteru i kontekstu tego wydarzenia, ale 
pokazuje WYD niejako „od kuchni”, od strony organizacyjnej, szczególnie w wymiarze działań medialno-komunikacyjnych. Autorki pracy nie tylko prezentują ten communication case study z pozycji zewnętrznych podmiotów zainteresowanych badawczo wymiarem komunikacyjnym WYD, ale dostarczają nam wiedzy „od wewnątrz” na temat działań komunikacyjnych podejmowanych w szerokim czasokresie przygotowania, przebiegu i rezultatów Światowych Dni Młodzieży Kraków 2016. Ta wiedza wewnętrzna jest cennym materiałem źródłowym, niedostępnym innym autorom, gdyż autorki publikacji dysponowały takimi materiałami, które były tylko w ich dyspozycji i wynikały $\mathrm{z}$ ich osobistych doświadczeń. Metoda pozyskiwania materiałów źródłowych i danych badawczych poprzez własną obserwację i uczestnictwo w badanych fenomenach jest bardzo cenną metodą, niedostępną dla większości badaczy wydarzeń medialnych, którym dane jest korzystać tylko z materiałów dostępnych zewnętrznie.

Monografia składa się z pięciu części, które w sposób postępujący i komplementarny prezentują tytułową problematykę i założone przez autorki cele: What this book is about, World Youth Days, WYD 2016 Kraków, WYD 2016 communication case study, WYD evaluations. Najbardziej obszerne są części czwarta i piąta, które stanowią rdzeń pracy zaznaczony także w jej podtytule jako studium wymiaru medialno-komunikacyjnego Światowych Dni Młodzieży Kraków 2016. We wszystkich częściach autorki w sposób postępujący metodologicznie i merytorycznie ukazują problematykę WYD, koncentrując się na ich komunikacyjnym wymiarze. Praca ma interesującą metodologicznie kompozycję. Trzy pierwsze części mają charakter informacyjno-syntetyczny i dostarczają czytelnikom konkretnej wiedzy na temat historii i specyfiki WYD. Natomiast części czwarta i piąta zawierają konkretną wiedzę źródłową, dokumentacyjną i statystyczną, uzupełnioną analizami badawczymi i ewaluacyjnymi. W części piątej autorki dokonują swoistego podsumowania, które poprzez zawarte dane ewaluacyjne jest próbą spojrzenia w przyszłość organizacji WYD.

Należy podkreślić nowatorstwo i ważność recenzowanej pracy w następujących pięciu aspektach. Po pierwsze, warto docenić język publikacji. Publikacja wydana w Polsce w języku angielskim jest adresowana nie tylko do Polaków, ale bardziej do czytelników i odbiorców na świecie, co - zakładając także jej elektroniczną dystrybucję - gwarantuje szeroki odzew światowy. Nie bez znaczenia jest również to, że książka została napisana oryginalnie w języku angielskim przez Polkę Paulinę Guzik i Amerykankę Cecylię O’Reilly. Po drugie, chodzi o walor poznawczy pracy. Zawiera ona syntetyczną wiedzę na temat WYD o charakterze źródłowym i dokumentacyjnym, przepracowaną przez autorki analizami badawczymi, porównawczymi, ewaluacyjnymi itd. $Z$ tej racji publikacja w przyszłości może stanowić dla wielu badaczy WYD podstawowy materiał źródłowy. Po trzecie, walorem pracy jest jej główna problematyka badawcza, a wiec ukazanie wielorakiego wymiaru medialno-komunikacyjnego WYD. Autorki pokazują stronę organizacyjną departamentu komunikacji WYD 2016, strategię komunikacyjną i promocyjną WYD, działania z zakresu media relations i public relations, medialne zarządzanie sytuacjami kryzysowymi itd. Ponadto autorki pokazują przykładową medialną recepcję WYD oraz próbują dokonać oceny tej recepcji i skuteczności podjętych działań promocyjno-komunikacyjnych WYD. Po czwarte, walorem pracy jest "odśrodkowy" charakter pozyskiwanej wiedzy. Tekst książki odzwierciedla nie tylko 
kompetencje naukowo-badawcze autorek, ale także ich doświadczenia komunikacyjne oraz ich praktyczne zaangażowanie w działania komunikacyjne WYD. Autorki znają bowiem analizowane działania komunikacyjne „od środka”, często uczestnicząc w tych działaniach, ale także potrafią popatrzeć na ukazywane zjawiska „od zewnątrz”, opierając się na empirycznych danych i analizując zewnętrzną recepcję działań komunikacyjnych WYD. Po piąte, ważnym walorem pracy jest jej promocyjno-popularyzatorski cel. Nie chodzi o charakter pracy, ale o zakładany i zaznaczony w tytule cel: Learnings for the Future. Publikacja nie tylko promuje w świecie Światowe Dni Młodzieży Kraków 2016 jako największe dotychczasowe wydarzenie europejskie dla młodych, ale dostarcza kompetentnej wiedzy i danych dokumentacyjnych dla organizatorów i uczestników przyszłych podobnych wydarzeń. Publikacja stanie się szczególnie cenną i nieodzowną pomocą dla organizatorów WYD w Panamie. Podsumowując ten wątek mojej oceny, chcę podkreślić walor poznawczo-edukacyjny recenzowanej publikacji, co jest ważne zarówno od strony ryzyka wydawcy, jak i od strony potencjalnych odbiorców tej publikacji, którzy sięgną po nią nie tylko po to, by poznać bliżej i głębiej fenomen WYD, ale także po to, by zaczerpnąć inspiracji do własnych działań komunikacyjnych w organizacji różnych wydarzeń. Ta pięciowymiarowa specyfika i ważność publikacji podkreśla jej badawczy i poznawczy walor, za co należy docenić trud i zaangażowanie dokumentacyjne autorek. 